DE LEGA LATA

Jurnal Ilmu Hukum

FAKULTAS HUKUM UMSU

\title{
PERLINDUNGAN HUKUM KEKAYAAN INTELEKTUAL TERHADAP PENGRAJIN KERAJINAN TANGAN
}

\author{
Ida Nadirah \\ Fakultas Hukum Universitas Muhammadiyah Sumatera Utara \\ Jl. Kapten Mukhtar Basri No. 3, Medan - Sumatera Utara, Indonesia \\ Telp: (061) 6622400, Fax: (061) 6623474, 6631003), Kode Pos 20238 \\ Email: idanadirah@umsu.ac.id
}

\begin{abstract}
Abstrak
Pengaturan hak kekayaan intelektual terhadap pengrajin kerajinan tangan di Indonesia merupakan hasil transplantasi dari TRIP's Agreement dan Paris Convention for the Protection of Industrial Property (Konvensi Paris) yang berparadigma kapitalis. Peraturan ini sulit untuk diimplementasikan secara optimal, karena nilai dan kultur yang melatarbelakangi berbeda. Namun karena konsekuensi yuridis dan psikologis, Indonesia telah menyepakati GATT (General Agreement of Tariff and Trade) dan sepakat pula kerangka GATT/WTO (World Trade Organization), akhirnya Indonesia meratifikasi melalui UU No. 7 Tahun 1994. Harapan besar Undang-undang Hak Kekayaan Intelektual dapat diimplementasikan, tetapi fakta sebaliknya Undang-Undang Nomor 31 Tahun 2000 masih belum optimal berlaku terutama oleh pengrajin kerajinan tangan. Hal ini terbukti jumlah pendaftar semakin lama justru semakin berkurang karena terjadi degradasi kreativitas dan belum memenuhi nilai-nilai keadilan sosial. Langkah alternatif dalam menjembatani adalah dilakukan internalisasi nilai-nilai Pancasila ke dalam Undang-Undang Hak Kekayaan Intelektual sebagai "roh atau jiwa" yang diharapkan mampu memberikan keadilan bagi masyarakat pengrajin kerajinan tangan, sehingga dapat memacu pengembangan kreativitas pengrajin kerajinan tangan selanjutnya. Penelitian ini mengangkat beberapa permasalahan yang diantaranya bagaimana perlindungan hak desain industri, alasan kurangnnya pengharaan pendesain terhadap kreasinya dan apa yang menjadi posisi rawan dari pengrajin kerajinan tangan. Jenis penelitian yang digunakan dalam tulisan ini adalah penelitian hukum dengan jenis pengumpulan data dengan cara studi pustaka.
\end{abstract}

Kata Kunci: Perlindungan, Hak Kekayaan Intelektual, Pengrajin, Kerajinan Tangan.

\begin{abstract}
The arrangement of intellectual property rights of handicraft craftsmen in Indonesia is the result of transplants from the TRIP's Agreement and the Paris Convention for the Protection of Industrial Property (Paris Convention) which has a capitalist paradigm. This regulation is difficult to implement optimally, because the background values and cultures are different. However, due to juridical and psychological consequences, Indonesia has agreed on the GATT (General Agreement of Tariff and Trade) and also agreed on the GATT / WTO (World Trade Organization) framework, finally Indonesia ratified through Law No. 7 of 1994. The great expectation of the Intellectual Property Rights Law can be implemented, but the fact is that Law No. 31 of 2000 is still not optimally applied mainly by handicraft craftsmen. This is proven by the fact that the number of applicants is getting worse because of the degradation of creativity and not fulfilling the values of social justice. An alternative step in bridging is to internalize the Pancasila values into the Intellectual Property Rights Act as "spirit or soul" which is expected to be able to provide justice for the community of handicraft craftsmen, so that it can spur the development of the creativity of the next handicraft craftsmen.
\end{abstract}

Keywords: Protection, Intellectual Property Rights, Handicraft Craftsmen.

E-ISSN: 2477-7889 I ISSN: 2477-653XXI URL: http://jurnal.umsu.ac.id/index.php/delegalata 
DE LEGA LATA

Jurnal Ilmu Hukum

FAKULTAS HUKUM UMSU
Perlindungan Hukum Kekayaan Intelektual...(Ida Nadirah)

Volume 5 Nomor 1, Januari - Juni 2020, 37-50

DOI: https://doi.org/10.30596/dll.v4i2.3176

\section{PENDAHULUAN}

Lahirnya Undang-Undang Hak Kekayaan Intelektual di Indonesia dilatarbelakangi oleh adanya 2 (dua) alasan. Alasan pertama, terkait masalah kewajiban Indonesia sebagai anggota World Trade Organization (WTO) yang harus menyediakan peraturan yang lebih baik tentang perlindungan hak kekayaan intelektual pengrajin kerajinan tangan. Kedua, berhubungan dengan tekad pemerintah untuk memberikan perlindungan yang efektif terhadap berbagai bentuk pelanggaran terhadap hak kekayaan intelektual pengrajin kerajinan tangan seperti penjiplakan, pembajakan atau peniruan. Upaya perlindungan yang lebih komprehensif tersebut diharapkan dapat menjadi faktor pendorong untuk meningkatkan daya kreativitas pada pengrajin kerajinan tangan sebagai wahana untuk melahirkan para pengrajin kerajinan tangan yang produktif (Tomi Suryo Utomo, 2009, h. 225).

Kebijakan ikut sertanya Indonesia sebagai anggota World Trade Organization (WTO) sebagai salah satu bukti keseriusan pemerintah dalam mendukung sistem perekonomian bebas/terbuka yang secara tidak langsung memacu perusahaan-perusahaan untuk lebih meningkatkan daya saing. Ratifikasi terhadap Agreement Establishing the World Trade Organization (Persetujuan Pembentukan Organisasi Perdagangan Dunia) mencakup Agreement on Trade Related Aspects of Intellectual Property Rights (Persetujuan TRIP's) melalui pengesahan Undang-Undang Nomor 7 Tahun 1994. Kondisi tersebut telah mendukung ratifikasi Paris Convention for the Protection of Industrial Property (Konvensi Paris) dengan keputusan Presiden Nomor 15 Tahun 1997 dan keikutsertaan Indonesia dalam the Haque Agreement (London Act) concerning the International Deposit of Industrial Designs. Prinsip pengaturannya adalah pengakuan kepemilikan atas karya intelektual yang memberikan kesan estetis dan dapat diproduksi secara berulang-ulang serta dapat menghasilkan suatu barang dalam bentuk 2 (dua) atau 3 (tiga) dimensi (Ditjen HKI, 2007, h. 229).

Indonesia menyikapi dan mengambil suatu langkah cerdas. Dengan keberadaan nilainilai dan kulturnya masing-masing dalam upaya untuk bisa menerapkan Undang-Undang Hak Kekayaan Intelektual yang berparadigma kapitalis bertolak belakang dengan paradigm yang telah berakar di Negara Indonesia. Namun karena konsekuensi yuridis dan psikologis Indonesia telah menyepakati GATT (General Agreement on Tariff and Trade) dan sepakat pula kerangka GATT/WTO (World Trade Organization), dan diratifikasi melalui UU No. 7 Tahun 1994, berharap besar Undang-Undang Hak Kekayaan Intelektual tersebut dapat diimplementasikan dan bermanfaat bagi masyarakat Indonesia pada umumnya termasuk ahli teknologi, walaupun faktanya sampai kini berbeda. Sehingga akhirnya pun kembali menjadi suatu polemik dan persoalan yang cenderung menempatkan negara pada posisi yang sulit dan tertindas (Ok. Saidin, 2004, h. 6).

Awalnya hak kekayaan intelektual diatur pada abad ke-18 di Inggris masing berbentuk 2 (dua) dimensi, menjadi bentuk 3 (tiga) dimensi diatur melalui Sculpture Copyright Act 1798 hanya meliputi model manusia dan binatang. Tanggal 20 Maret 1883 The Paris Convention form the Protection of Industrial Property (Paris Convention). Pasal 5 Paris Convention menyatakan bahwa Hak Kekayaan Intelektual harus dilindungi di semua negara anggota Paris Convention (Perlindungan Desain Industri di Indonesia dan Ketentuan Internasional di Bidang Desain Industri. Mayana, R. F. 2011: 4). Fakta yang terjadi berbeda, karena perlindungan 


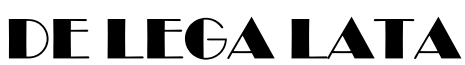

Jurnal Ilmu Hukum

FAKULTAS HUKUM UMSU
Perlindungan Hukum Kekayaan Intelektual...(Ida Nadirah)

Volume 5 Nomor 1, Januari - Juni 2020, 37-50

DOI: https://doi.org/10.30596/dll.v4i2.3176

hukum yang diharapkan belum memnuhi rasa keadilan sosial. Upaya perlindungan yang lebih komprehensif terus dilakukan untuk meningkatkan daya kreativitas para pengrajin kerajinan tangan dan sebagai wahana untuk melahirkan para pengrajin kerajinan tangan yang produktif (Tomi Suryo Utomo, 2009, h. 225).

Pasal 1 ayat (1) Undang-undang Desain Industri menyebutkan:

Desain Industri adalah suatu kreasi tentang bentuk, konfigurasi, atau komposisi garis atau warna, atau garis dan warna, atau gabungan daripadanya yang berbentuk tiga dimensi atau dua dimensi yang memberikan kesan estetis dan dapat diwujudkan dalam pola tiga dimensi atau dua dimensi serta dapat dipakai untuk menghasilkan suatu produk, barang, komoditas industri, atau kerajinan tangan.

Pasal ini kurang mencerminkan rasa keadilan sosial maupun kebersamaan kultur atau budaya bangsa Indonesia. Di sisi lain kekayaan budaya dan etnis bangsa Indonesia yang sangat beraneka ragam, baik dilakukan masyarakat berpendidikan rendah, menengah maupun tinggi, serta kreasi pun beraneka ragam bentuk maupun model, dengan pengorbanan waktu, tenaga dan materi sampai kini masih banyak yang belum diakomodasi dengan baik, sehingga kreasi yang bersifat unik tersebut belum mendapatkan perlindungan hukum. Perlindungan hukum merupakan penghargaan yang diberikan kepada mereka pengrajin kerajinan tangan yang mengajukan permohonan pendaftaran.

Teori perlindungan hukum dari Satjipto Raharjo, memberikan pengayoman terhadap masyarakat agar dapat menikmati semua hak yang sesuai hukum (Tomi Suryo Utomo, 2009, h. 54). Demikian juga Lili Rasjidi dan I.B. Wyasa Putra, ingin mewujudkan perlindungan yang sifatnya tidak sekadar adaptif dan fleksibel tetapi juga prediktif dan antisipatif (Lili Rasjidi dan I. B. Wyasa Putra, 1993, h. 118). Diperkuat pula oleh Sunaryati Hartono, bahwa hukum dibutuhkan dan diperuntukkan bagi mereka yang lemah dan belum kuat secara sosial, ekonomi dan politik untuk memperoleh keadilan social (Sunaryati Hartono, 1991, h. 55).

Upaya untuk mendapatkan perlindungan hukum yang diinginkan oleh manusia adalah terwujudnya ketertiban dan keteraturan antara nilai dasar dari hukum yakni adanya kepastian hukum, kegunaan hukum serta keadilan hukum, meski pada umumnya yang sering terjadi dalam praktek ketiga nilai-nilai dasar tersebut sering bersitegang, tetapi harus diupayakan ketiga nilai dasar tersebut bersamaan (Sunaryati Hartono, 1991, h. 55). Berbeda dengan Hadjon ada dua macam perlindungan hukum bagi rakyat preventif dan represif. Prinsip perlindungan hukum bagi rakyat Indonesia adalah prinsip pengakuan dan perlindungan terhadap harkat dan martabat manusia yang bersumber pada Pancasila dan prinsip negara hukum yang berdasarkan Pancasila (Phillipus M. Hadjon, 1987, h. 2).

Teori keadilan sosial, juga mewarnai sebagaimana terdapat pada alinea keempat pembukaan UUD 1945. Bahwa keadilan sosial menjjadi salah satu landasan dasar dari tujuan dan cita-cita negara (staatsidee) sekaligus sebagai dasar filosofis bernegara (filosofische grondslag) terdapat pada sila kelima dari Pancasila. Artinya, sudah sejak awal the founding parents mendirikan Indonesia atas pijakan untuk mewujudkan keadilan sosial baik untuk warga negaranya sendiri maupun masyarakat dunia. Relevansi Konstitusi teori keadilan dari John Rawls adalah bahwa prinsip-prinsip keadilan yang disampaikan sangat relevan bagi negaranegara dunia yang sedang berkembang, seperti Indonesia. 


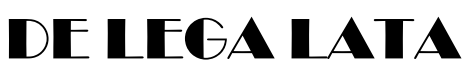

Jurnal Ilmu Hukum

FAKULTAS HUKUM UMSU
Perlindungan Hukum Kekayaan Intelektual...(Ida Nadirah)

Volume 5 Nomor 1, Januari - Juni 2020, 37-50

DOI: https://doi.org/10.30596/dll.v4i2.3176

Reward Theory yang memiliki makna pengakuan terhadap karya intelektual yang telah dihasilan oleh seseorang sehingga kepada kreator pengrajin harus diberikan penghargaan sebagai imbalan atas upaya-upaya kreatifnya dalam menemukan atau menciptakan karya-karya intelektual tersebut. Teori ini sejalan dengan prinsip yang bahwa inventor/pendesain yang telah mengeluarkan waktu, biaya serta tenaga dalam menghasilkan karya intelektualnya harus memperoleh kembali apa yang telah dikeluarkan tersebut, yang dikenal dengan Recovery Theory. Selain Reward Theory adalah Incentive Theory yang mengaitkan pengembangan kreativitas dengan memberikan insentif bagi para penemu/pencipta atau pengrajin tersebut. Dengan menganalisis ini dapat diraih keadilan sosial, yang sesuai dengan porsinya, sebagaimana yang terdapat nilai sila kelima Pancasila.

Ciri utama dalam pengrajin kerajian tangan adalah bahwa karya pengrajin yang dapat diwujudkan dalam pola atau cetakan untuk menghasilkan barang-barang dalam proses produksi yang dapat dilakukan secara berulang-ulang. Industrialisasi Indonesia telah berdampak pada transformasi struktural di Indonesia, yang ditandai dengan semakin tingginya kontribusi sektor industri dan beberapa sektor lainnya, kontribusi sektor pertanian semakin kecil pada tahun 1968, sektor industri manufaktur Indonesia memberi sumbangan sebesar 8,5 persen terhadap keseluruhan perekonomian (PDB), sedangkan sektor pertanian menjadi sektor tertinggi untuk perekonomian, dengan kontribusi sebesar 51 persen.

\section{METODE PENELITIAN}

Sesuai dengan permasalahan yang diteliti, penelitian ini merupakan penelitian hukum (legal research). Istanto, mengatakan penelitian hukum adalah penelitian yang diterapkan atau diberlakukan khusus pada ilmu hukum (Istanto, 2007, h. 29). Sejalan dengan Istanto, Marzuki mengatakan penelitian hukum adalah suatu proses untuk menemukan aturan hukum, prinsipprinsip hukum, maupun doktrin-doktrin hukum guna menjawab isu-isu hukum yang dihadapi (Marzuki, 2005, h. 35). Penelitian hukum normatif merupakan penelitian yang datanya bersumber pada data sekunder (Faisal, 2018, h. 145), oleh karena itu karena penelitian ini adalah normatif maka data yang digunakan adalah data sekunder.

Jenis pengumpulan data yang digunakan dalam penulisan ini adalah studi pustaka. Studi pustaka berarti penelitian yang menggunakan dokumen tertulis sebagai data, dan sumber data yang digunakan dalam penelitian ini mencakup bahan hukum primer, bahan hukum sekunder dan bahan tersier. Bahan hukum primer adalah bahan hukum yang mengikat atau yang membuat orang taat hukum, meliputi produk hukum yang menjadi bahan kajian dan produk hukum sebagai alat kritiknya (Rahmat Ramadhani, 2017, h. 142). Bahan hukum sekunder meliputi penjelasan bahan hukum primer berupa doktrin para ahli yang ditemukan dalam buku, jurnal, dan dalam website.

\section{PEMBAHASAN DAN ANALISIS}

Pasal 1 butir (1), Perlindungan Hukum diberikan pada bentuk luaran/tampilan luar (physical appearance) yang memberi kesan estetis dan bukan pada fungsi sebuah benda. Namun kesan estetis ini bersifat umum. Kreasi desan industri harus dipisahkan atau dibedakan dari benda itu, karena desain merupakan sebuah "konsep" yang diterapkan pada produk, barang, komoditas industri, atau kerajinan tangan dan tidak melekat menjadi satu dengan barangnya. 


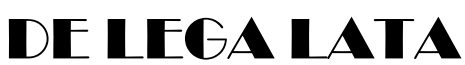

Jurnal Ilmu Hukum

FAKULTAS HUKUM UMSU
Perlindungan Hukum Kekayaan Intelektual...(Ida Nadirah)

Volume 5 Nomor 1, Januari - Juni 2020, 37-50

DOI: https://doi.org/10.30596/dll.v4i2.3176

"Pemegang hak desain industri" yang memiliki hak eksklusif dapat melaksanakan dan melarang orang lain yang tanpa persetujuannya.

Subyek hak desain industri meliputi: 1) pendesain atau yang menerima hak tersebut dari pendesain, 2) jika pendesain terdiri atas beberapa orang secara bersama, hak desain industri diberikan kepada mereka secara bersama, kecuali jika diperjanjikan lain. Pemegang hak desain industri adalah pihak yang untuk dan/atau dalam dinasnya desain industri itu dikerjakan, kecuali ada perjanjian lain dan perlindungan hukum desain industri menganut sistem konstitutif dengan prinsip "First to File Principle". Konsekuensinya, jika suatu desain industri yang dimiliki tidak terdaftar, maka tidak akan mendapatkan perlindungan hukum. Sebagai contoh, di Kabupaten Jepara memiliki banyak pendesain/kreator, banyak belum mendapat prioritas karena kreativitas yang dimiliki masyarakat belum diapresiasi dengan maksimal oleh pemerintah daerah. Sehingga Undang-undang Desain Industri belum dapat dimanfaatkan secara optimal khususnya "Pengrajin Kerajinan Tangan". Ada beberapa kendala yang timbul belum optimalnya hukum dapat diimplementasikan yang menurut Friedman karena substansi, struktur dan kulturnya belum sesuai dengan kondisinya. Substansi dari Undang-undang Desain Industri itu sendiri belum mampu memberikan perlindungan hukum yang mencerminkan nilai keadilan sosial, yang tidak mengakar dalam tradisi budaya masyarakat Indonesia yang tumbuh dalam tradisi hukum masyarakat Indonesia yang berakar pada budaya komunal (kebersamaan). Karena budaya Undang-Undang Desain Industri yang berlaku kini dari sudut historisnya, adalah transplantasi dari produk kaum Kapitalis-Liberal. Masyarakat Pancasila mencari dan mengutamakan keseimbangan antara hidup sebagai pribadi dan hidup sebagai warga masyarakat, antara kehidupan materi dan kehidupan rohani.

Sedangkan untuk mendapatkan perlindungan pengrajin kerajinan tangan maupun produknya, harus melalui pengajuan Permohonan Pendaftaran ke Ditjen HKI Departemen Hukum dan HAM RI. Di sisi lain: (1) Pendesain rata-rata adalah pengrajin kerajinan tangan merasa belum tertarik untuk mendaftar, karena ketidaktahuan mereka terhadap arti penting dampak pendaftaran, juga belum ada perhatian khusus dari Pemerintah Daerah terhadap Perlindungan Pendesain/Kreator Desain Industri, baik melalui upaya pemberdayaan pengrajin kerajinan tangan khususnya desain industri kerajinan tangan; (2) Belum faham kriteria desain industri yang termasuk dalam kategori bisa mendapatkan perlindungan hukum; (3) Belum mengerti dan memahami syarat-syarat yang harus dilengkapi untuk Permohonan Pendaftaran; (4) Belum tahu manfaat ekonomis dan yuridis dari Pendaftaran Desain Industri yang mereka ciptakan; (5) Kesulitan mengakses informasi dalam mengaplikasi Desain Industri ke Direktorat HKI Departemen Kehakiman dan HAM dan kurang sosialisasi dan Pemerintah Daerah terkait; (6) Sikap mistifikasi terhadap karya yang dihasilkan dan pengaruh konsep budaya (komunal) yang melekat pada konsep berpikir Pendesain/Kreator; (7) SDM kurang termotivasi secara optimal; (8) Tidak ada bimbingan dan pendampingan yang intensif serta tidak adanya pemberian/subsidi biaya; (9) Tidak adanya kebijakan pola jemput bola dari Pemda setempat sebagai wujud kepedulian atau perhatian dan bantuan dari Pemerintah Daerah dalam menyiasati atau sebagai dana pancingan; (10) Undang-undang tentang Perlindungan Pendesain pada Hukum Desain Industri belum memeuhi rasa keadilan sosial. Kekurang perhatian Pemerintah Daerah berdampak terjadinya beberapa kasus pembajakan/penyerobotan seperti Kasus "Dugaan Eksploitasi Folklor Jepara oleh Christoper Harrison-Inggris; Kasus penyerobotan E-ISSN: 2477-7889 I ISSN: 2477-653XXI URL: http://jurnal.umsu.ac.id/index.php/delegalata 


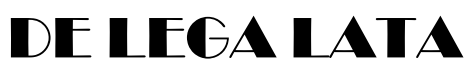

Jurnal Ilmu Hukum

FAKULTAS HUKUM UMSU
Perlindungan Hukum Kekayaan Intelektual...(Ida Nadirah)

Volume 5 Nomor 1, Januari - Juni 2020, 37-50

DOI: https://doi.org/10.30596/dll.v4i2.3176

pendaftaran yang dilakukan pengusaha mitra bisnis tanpa ijin, ke negara asal mitra kerjanya; yang berdampak terbalik desain tersebut justru didaftarkan oleh mitra bisnis di negara asal mitra. Seperti dalam sebuah event pameran dengan cara memotret, orang lain bisa mendapatkan hak secara legal.

Pemegang Hak Desain Industri dapat beralih atau dialihkan dengan cara pewarisan, hibab, wasiat, perjanjian tertulis, melalui perjanjian lisensi atau sebab-sebab lain yang dibenarkan oleh peraturan perundang-undangan. Pengalihan hak Desain Industri tersebut harus disertai dengan dokumen tentang pengalihan hak dan wajib dicatat dalam Daftar Umum Desain Industri, dengan membayar biaya, diumumkan dalam Berita Resmi Desain Industri.

\section{Perlindungan Hak Desain Industri}

Bagi masyarakat yang concern dalam bidang Hak Kekayaan Intelektual (HKI) mempertanyakan terkait dengan sistem Perlindungan Hukum dari HKI khususnya Desain Industri yang merupakan bagian dari HKI. Terbukti sampai kini Indonesia belum mampu memberikan perlindungan hukum dan pengelolaan atas kekayaan intelektual masyarakat Indonesia secara optimal, dan belum efektif. Salah satu faktor penyebab keengganan masyarakat pengrajin untuk mendaftarkan desain kreatifnya, di samping kewenangan pengadministrasian HKI dan pengelolaan HKI di daerah belum dibentuk.

Pada prinsipnya setiap orang atau badan (kreator/pendesain) yang telah mendapat persetujuan dari Permohonan Pendaftaran Desain Industri ke Direktorat HKI maka mendapat Hak Desain Industri atau berhak untuk monopoli selama 10 (sepuluh) tahun. Pemegang Hak Desain Industri ini mempunyai hak untuk memberi izin atau melarang orang lain untuk membuat, menjual, mengimpor, mengekspor atau mengedarkan barang yang telah diberikan Hak Desain Industri. Abdul Bari Azed menegaskan (Wawancara dengan Abdul Bari Azed, 25 Oktober 2014), Desain Industri akan mendukung peningkatan pertumbuhan ekonomi. Bagaimanapun perlindungan terhadap Desain Industri akan meningkatkan desain kreativitas dalam menciptakan bentuk produk yang beragam di sektor manufaktur serta kerajinan. Namun, pemerintah sangat minim melakukan sosialisasi mengenai Desain Industri, sehingga wajar bila kemudian ada ketidaktahuan masyarakat terhadap Desain Industri. Padahal fasilitas keringanan telah digulirkan untuk pengrajin kerajinan tangan tetapi tingkat realisasinya masih sangat rendah (http://www.sinarharapan.co.id/ekonomi/industri/2003/0910/ind1.html). Ada biaya khusus yang diberikan untuk pengrajin kerajinan tangan, pelajar atau mahasiswa dalam mendaftarkan desainnya. Kelompok ini mendapat keringanan 50 persen dari Rp 600.000 setiap kali pendaftaran, berdasar Peraturan Pemerintah Nomor 50 Tahun 2001.

\section{Kurangnya Penghargaan Pendesain Terhadap Kreasinya}

Desain merupakan aset produk, bagian dari kreativitas manusia, dimana kreativitas ini perlu ditingkatkan supaya mampu bersaing di perdagangan global. Industri dan desain menjadi 2 (dua) hal yang tidak terpisah karena industri cenderung rendah dalam pengembangan desain. Bahkan sering terdengar sebuah kreativitas dibajak, tetapi pembajakan desain industri ini sering dianggap sepi, bahkan kasus pembajakan yang muncul ke permukaan nyaris tidak ada. Padahal sebuah desain, sangat mudah untuk dijiplak atau dibajak, seperti contoh dalam pameran khususnya pengrajin kerajinan tangan pada umumnya akan memamerkan produk yang belum 


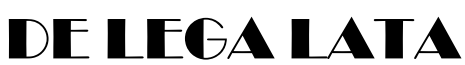

Jurnal Ilmu Hukum

FAKULTAS HUKUM UMSU
Perlindungan Hukum Kekayaan Intelektual...(Ida Nadirah)

Volume 5 Nomor 1, Januari - Juni 2020, 37-50

DOI: https://doi.org/10.30596/dll.v4i2.3176

didaftarkan. Padahal dengan hanya memotret produk itu, membuatnya dengan desain yang sama dan mereka yang kreatif, tetapi dengan cara "curang" mendaftarkan desain tersebut atas nama dirinya maka dia mendapatkan hak atas desain produk tersebut. Jadi secara tidak langsung seseorang bisa mendapatkan hak desain industri yang seharusnya milik orang lain secara legal, hal ini seringkali terjadi di Kabupaten Jepara, maupun di tempat-tempat lainnya.

Imam Buchori Zaenuddin seorang Guru Besar Desain Produk Industri ITB, menyampaikan ada kegamangan dari industri untuk mengembangkan produk yang siklus hidupnya berjangka panjang, karena beranggapan bahwa investasi tersebut penuh resiko, bahkan kurangnya wawasan industri tentang desain; serta adanya anggapan bahwa penelitian desain butuh biaya yang mahal, di sisi lain belum adanya kejelasan hubungan antara industri dengan pendesain. Hal ini dapat dimengerti, sehubungan banyaknya pembajakan merajalela sehingga "pendesain seolah-olah hanya sebagai buruh, sedangkan yang memperoleh pendaftaran adalah orang lain, bahkan yang lebih mengerikan kepemilikan hak desain tersebut adalah orang asing."

Langkah kongkrit yang diupayakan Direktorat Jenderal HKI dengan memberi kesempatan pada pengrajin kerajinan tangan, pelajar dan mahasiswa agar mendapat pembebasan atas biaya pendaftaran seperti yang dilakukan Korea, yang berdampak desain industri sangat berkembang di negara ginseng tersebut. Disampaikan Imam Buchori (Sinar Harapan, 2003), bahwa Korea mengalami pertumbuhan ekonomi yang sangat pesat adalah karena kebijakan pemerintah dalam memberdayakan desain industrinya. Korea sangat ambisius menjadikan negaranya sebagai design leading countries. Bahkan secara khusus membentuk lembaga yang diserahi tugas mempromosikan desain produk, yakni Korean Industrial Design Promotion. Lembaga ini dengan serius melakukan riset desain industri yang bersifat fundamental. Pemerintah Korea mengalokasikan dana riset untuk jangka 5-10 tahun yang jumlahnya sangat besar, namun hasilnya harus memberikan konttribusi nyata bagi pengembangan ekonomi nasional. Pemerintah Taiwan telah mempelopori pendirian Design Center sejak 1990 untuk membantu industri mereka dalam mengaplikasikan desain, bahkan Korea Selatan selangkah lebih maju. Desain Produk Industri telah menjadi agenda nasional dalam Committee of Globalization Policy. Di Malaysia, pemerintah membentuk Majelis Rekabentuk Malaysia (MRM) yang bernaung di bawah Kementerian Industri dan Perdagangan yang berfungsi menyusun agenda-agenda pemerintah dalam pemberdayaan Desain Produk Indutsri menyambut era pasar bebas.

Strategi ini harus diapresiasi dengan baik dan konsekuen pemerintah sampai saat ini masih mencari bentuk perlindungan desain industri. Banyak kelemahan-kelemahan, sehingga memberi peluang bentuk kecurangan, permohonan kepemilikan hak desain industri akan dikeluarkan terhadap semua pemohon pertama, apabila tidak ada yang mengajukan keberatan. Siapa yang lebih dulu mendaftarkan dan tidak ada oposisi, maka dikeluarkan sertifikat hak desain industri.

Berdasarkan Pasal 2 ayat (1) UU Nomor 31 Tahun 2000 tentang Desain Industri bahwa hak desain diberikan adalah desain industri baru, bukan desain industri yang sudah lama. Namun dimungkinkan desain yang didaftar adalah desain lama, karena sistem pendaftaran tidak memungkinkan adanya pemeriksaan subtantif seperti paten atau merek, permohonan dikabulkan. Hal ini sejalan dengan TRIP's Agreement dan Paris Convention yang mengatur 


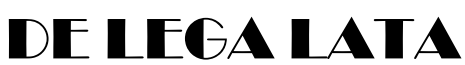

Jurnal Ilmu Hukum

FAKULTAS HUKUM UMSU
Perlindungan Hukum Kekayaan Intelektual...(Ida Nadirah)

Volume 5 Nomor 1, Januari - Juni 2020, 37-50

DOI: https://doi.org/10.30596/dll.v4i2.3176

tentang desain industri yang dapat dilindungi yaitu desain yang "baru" (original), dan/atau yang secara signifikan "berbeda" dengan desain industri sebelumnya (significantly differ from known designs) (Insan Budi Maulana, 2010, h. 7).

Berbeda dengan Korea yang menganut sistem fully examination atau pemeriksaan secara penuh. Pemeriksaan ini meminimalkan bentuk kecurangan, karena setiap pengajuan permohonan hak desain industri akan diperiksa latar belakang produk tersebut. Tetapi sistem ini butuh biaya yang besar, pemerintah harus mampu menyediakan sejumlah dana sebagai kompensasi dari sistem ini. Bahkan saat ini perhatian pemerintah lebih mendorong lahirnya kreativitas, yang diharap kreativitas dapat meningkatkan nilai jual sehingga semakin kompetitif. Seperti halnya desain tenun kain ikat akan semakin terlihat indah dan menarik apabila kain tenun ikat tersebut dirancang dalam bentuk aneka desain/rancangan baju yang menjadi "trend" di kalangan masyarakat. Melalui rancangan/desain baju yang bagus, "trendy" dan "elegant" akan memberikan nilai tambah bagi kain tenun ikat tersebut. Dari sinilah peran para desainer untuk mampu menciptakan desain-desain baju yang bagus dan menarik bagi semua kalangan usia, sehingga kain tenun ikat, sebagai produk nasional bangsa, dapat menjadi alternatif pilihan baju untuk berbagai acara formal maupun informal. Di samping itu juga diperlukan kreativitas dari para pengrajin kain tenun agar dapat menghasilkan/melahirkan motif-motif tenun yang baru yang dapat diterima pasar, baik pasar domestik maupun internasional.

Kain tenun ikat yang berasal dari masing-masing daerah telah menjadi komoditas ekspor yang potensial dalam memberikan keuntungan bagi bangsa Indonesia pada umumnya dan masyarakat daerah setempat pada khususnya. Motif-motif yang berasal dari masing-masing daerah merupakan kekayaan intelektual, bidang desain industri, khususnya desain tekstil, yang patut untuk dilestarikan, dilindungi dan bahkan dikembangkan. Melalui upaya pelestarian dan perlindungan hukum diharapkan motif-motif tenun ikat tidak musnah atau diambil alih oleh orang lain atau negara lain.

Kain tenun ikat sebagai produk nasional bangsa Indonesia, dalam pemasarannya baik ke pasar domestik maupun internasional tentunya menggunakan merek dagang yang menjadi simbol dan "image" dari masing-masing perusahaan. Peran merek dalam hal ini sangat penting karena merek menunjukkan identitas perusahaan asal kain tenun ikat, mutu (kualitas), dan juga sebagai "image" perusahaan yang memproduksi dan memasarkan kain tenun ikat tersebut.

Seperti halnya yang terdapat pada hukum paten mengambil jangka waktu monopoli yang terbatas, dan melalui pendaftaran yang memberikan hak kepada pemilik/pemegang hak atas desain untuk menghentikan pihak lain untuk memproduksi produk dengan desain yang sama, dan konsep kebaharuan pada desain merupakan syarat mutlak agar suatu desain dapat didaftarkan. Dalam hal ini desain industri meminjam konsep ide-ide menjadi bentuk-bentuk fisik yang merupakan perwujudan dari ide (Ranti Fuaza Mayana, 2004: 48).

Di negara maju, kesadaran perlunya mendaftarkan hak desain industri sangat luar biasa yang berbanding terbalik dengan Indonesia, seperti Korea yang mampu mendongkrak perekonomiannya desain lewat industry (http://sinarharapan.co.id/ekonomi/industri/2003/0910/ind.html). Kreativitas, merupakan asset intangible yang sulit untuk dihitung, namun bukan berarti tidak usaha untuk diperhitungkannya. Karena seperti reputasi seseorang maupun "knowhow" yang ada dalam diri individu memang tidak bisa diakui sebagai harta lembaga maupun perusahaan, karena seperti angin, bisa hilang, E-ISSN: 2477-7889 I ISSN: 2477-653XXI URL: http://jurnal.umsu.ac.id/index.php/delegalata 


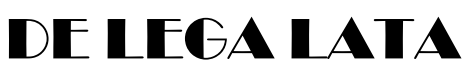

Jurnal Ilmu Hukum

FAKULTAS HUKUM UMSU
Perlindungan Hukum Kekayaan Intelektual...(Ida Nadirah)

Volume 5 Nomor 1, Januari - Juni 2020, 37-50

DOI: https://doi.org/10.30596/dll.v4i2.3176

musnah, bahkan juga bisa menipu seolah-olah ada, tetapi tidak ada. Bahwa Hak Kekayaan Intelektual (HKI) adalah hak yang timbul dari hasil imaginasi, olah kerja otak, perasaan dan karsa manusia untuk menghasilkan suatu karya, inovasi dan kreativitas intelektual yang berguna bagi kehidupan umat manusia. Dikatakan bahwa HKI dapat menjadi Penggerak Pertumbuhan Perekonomian yang menjadi publikasi WIPO.

\section{Posisi Rawan Dari Pengrajin Kerajinan Tangan}

Kesadaran terhadap perlindungan hak kekayaan intelektual sebagai sesuatu hal yang dibutuhkan. Banyaknya penjiplakan atau peniruan terhadap desain industri, menunjukkan belum adanya rasa kepedulian kreator/pendesain terhadap apa yang dimiliki terhadap kreativitas intelektualnya. Padahal jika dicermati sebagai upaya untuk mendapatkan kreativitas adalah butuh peluang waktu, biaya, tenaga dalam melakukan percobaan yang sulit untuk diperhitungkan dengan uang. Yang sering terjadi adalah:

1. Kurangnya pemberdayaan pengrajin kerajian tangan melalui perlindungan hukum desain industri;

2. Faktor-faktor penghambat para pengrajin/pendesain dalam pemberdayaan pengrajin kerajinan tangan disebabkan: Satu, belum memahami tentang desain industri; Dua, belum memahami manfaat secara ekonomis dan yuridis dari pendaftaran hak atas desain industri yang mereka ciptakan; Tiga, kurang sosialisasi; Empat, pengaruh konsep budaya (komunal) yang melekat pada konsep berpikir pengrajin kerajinan tangan; Lima, tidak mengetahui syarat yang harus dilengkapi; Enam, tidak mengetahui kriteria dari desain yang dapat dimohonkan pendaftarannya; Tujuh, tidak tahu tata cata untuk mengajikan permohonan pendaftarannya; Delapan, takut terbeban pajak yang tinggi; Sembilan, takut berdosa, karena menganggap bahwa kreativitas yang dimiliki didapat dari milik nenek moyanng; Sepuluh, tidak mempunyai biaya/modal untuk mendaftarkan. Dampaknya adalah: terjadi pembajakan seperti: Kasus Hak Cipta Mebel Ukir yang diduga terjadinya Eksploitasi Folklor Jepara oleh Christoper Harrison di Inggris.

Sesuatu yang tidak menyenangkan akan terjadi apabila kepemilikan desain baru yang tidak didaftarkan ke Ditjen HKI dengan sengaja didaftarkan oleh orang lain . Secara moral kreasi desain tersebut memang bukan miliknya tetapi dengan sengaja ingin menguasainya dengan cara tidak benar. Menyikapi kondisi seperti ini pihak yang berkompeten harus mengambil sikap dengan melakukan sosialisasi yang efektif dan sekaligus memberikan bantuan berupa biaya untuk mengajukan Permohonan Pendaftaran ke Direktorat Jenderal HKI agar mendapatkan Perlindungan Hukum secara inheren dari instansi terkait.

Kelemahan etika dalam berbisnis, pemasaran dan kurang berfungsinya organisasi pengusaha turut berperan sebagai pemicu dominasi pasar di antara para pengusaha, terutama dengan cara meniru desain yang telah ada tanpa melalui perjanjian lisensi sehingga terjadinya persaingan usaha yang curang, berdampak tidak stabilnya roda ekonomi.

Terkait Akses informasi perlindungan HKI, pengrajin harus melakukan penelusuran informasi HKI dengan mendatangi Kantor HKI di negara yang menjadi tujuan pasar, namun terbentur dengan masalah biaya, penelusuran melalui internet merupakan suatu solusi yang lebih tepat. Ketidakpedulian masyarakat terhadap pentingnya Perlindungan Desain Industri dan 


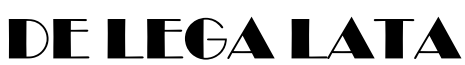

Jurnal Ilmu Hukum

FAKULTAS HUKUM UMSU
Perlindungan Hukum Kekayaan Intelektual...(Ida Nadirah)

Volume 5 Nomor 1, Januari - Juni 2020, 37-50

DOI: https://doi.org/10.30596/dll.v4i2.3176

eksistensi UU No. 31 Tahun 2000 tentang Desain Industri mengkhawatirkan. Berbeda di negara maju, sebagai contoh dapat dikemukakan pendaftaran paten dan desain produk untuk produk rotan yang terdaftar di USPTO (United State Patent and Trade Mark Office). Kenyataan ini sejalan dengan data yang diperoleh dari Ditjen HKI tentang minimnya Pendaftaran Desain Industri dari kalangan pengrajin kerajinan tangan. Dengan berlakunya UU No. 31 Tahun 2000, Pendesain akan berada pada situasi yang menghadapkan mereka dengan pilihan yang beragam. Pilihan (1) adalah tidak mendaftar desain kerajinan tangan mereka, yang menyebabkan pengrajin tidak akan pernah mendapatkan perlindungan hukum. Pilihan (2) tidak mendaftarkan, tetapi mempublikasikan desain kerajinan tangan juga akan mempunyai resiko akan ditiru pihak lain.

Pengrajin yang kerajinan tangnnya ditiru dan dipasarkan oleh rekan-rekan sesama pengerajin yang mengakibatkan kerugian baginya, namun tidak menuntut berdasarkan pertimbangan kebersamaan. Namun ada pula setelah didaftar ternyata ada pihak lain yang merasa berkeinginan untuk membuat kerajinan tangan tersebut, kemudian dengan tanpa izin atau tanpa melakukan perjanjian lisensi langsung menjiplak. Contoh konkret adalah yang dialami PT. Antara Kusuma dimana kereta dorong/sorong besi dengan merek SUN yang mereka produksi telah juga diproduksi, diedarkan, diekspor dan dijual oleh PT. Sun Industri, padahal desain industri tersebut telah didaftarkan di Direktorat Desain Industri, Tata Letak, Sirkuit Terpadu dan Rahasia Dagang Direktorat Jenderal Hak Kekayaan Intelektual RI dengan sertifikat No. ID 0.002.193. Kasus ini telah diperkarakan ke pengadilan, dan pada pengadilan tingkat I dan II dimenangkan oleh PT. Sun Industri, sedangkan pada tingkat kasasi dimenangkan oleh PT. Antara Kusuma. Hal semacam ini sebenarnya dapat dihindari dengan pendekatan dan pola yang aman jika di antara mereka dibuat suatu perjanjian lisensi satu sama lain jika satu karya desain digunakan secara bersama. Perjanjian ini dikenal dengan perjanjian lisensi yang memberi hak kepada penerima lisensi untuk menggunakan desain milik (http://www.investor.co.id/opini/urgensi-pendidikan-desain-dan-inovasi-produk/30725).

Pengembangan pengetahuan sangat penting sehubungan terjadinya transformasi usaha pengrajin kerajinan tangan industri kreatif. Tren dunia menunjukkan bahwa profesi seni dan desain produk semakin cerah dan bisa menghasilkan devisa yang sangat besar bagi negara. Sehingga pengrajin kerajinan tangan industri kreatif semakin berkepentingan membuat produknya menjadi semakin indah dan menarik secara fisik serta bisa menjalar ke seluruh penjuru dunia dalam waktu yang relative singkat. Dengan demikian, kemampuan high concept menjadi sangat penting dan dibutuhkan.

Kecenderungan pendekatan terhadap masalah pengrajin kerajinan tangan dilakukan secara parsial, hanya mencari solusi masalah desain atau bahan baku saja. Padahal sesuai prinsip rantai nilai, pemetaan mulai proses pengadaan bahan baku sampai pasar akhir penting untuk menjaga keberlangsungan usaha.

\section{Perlindungan Hukum Yang Belum Menyentuh}

Aktualisasi implementasi terhadap keikutsertaan Indonesia sebagai anggota WTO dengan konsekuensi melaksanakan ketentuan Agreement on Trade Related Aspects of Intellectual Property Rights (Persetujuan TRIP's) sesuai dengan Undang-undang NOmor 7 Tahun 1994 tentang Pengesahan Agreement Establishing the World Trade Organization 


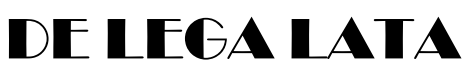

Jurnal Ilmu Hukum

FAKULTAS HUKUM UMSU
Perlindungan Hukum Kekayaan Intelektual...(Ida Nadirah)

Volume 5 Nomor 1, Januari - Juni 2020, 37-50

DOI: https://doi.org/10.30596/dll.v4i2.3176

(Persetujuan Pembentukan Organisasi Perdagangan Dunia) ternyata masih terhambat cukup serius, karena terbukti transplantasi tersebut masih mengandung kelemahan-kelemahan dalam upaya untuk mengefektifkan melalui harmonisasi ketentuan perundang terhadap desain industri. Harmonisasi yang sebenarnya adalah merupakan hasil transplantasi tersebut dari sistem hukum beraliran kolonial ke sistem Hukum HKI dengan versi sistem ekonomi kerakyatan dalam artian bahwa, bagaimana kreasi ekspresi intelektual masyarakat yang berpotensi HKI, pengaturannya didasarkan pada nilai-nilai Pancasila dalam bingkai demokrasi ekonomi. Perlindungan HKI yang berlaku di Indonesia kini melekat dan menganut sistem hukum kapitalis yang jauh dari nilai-nilai Pancasila, dimana sistem ini bertentangan dengan filosofi dan budaya masyarakat Indonesia. Padahal Indonesia merupakan salah satu negara yang turut serta menandatangani persetujuan pembentukan Organisasi Perdagangan Dunia atau World Trade Organization (WTO) yang termasuk di dalamnya perjanjian mengenai aspek perdagangan yang terkait dengan Hak Kekayaan Intelektual/IPR (Agreement on Trade Related Aspects of Intellectual Property Rights). Perjanjian internasional tersebut telah diratifikasi oleh Indonesia melalui Undang-undang Nomor 7 Tahun 1994 tentang Pengesahan Agreement Establishing The World Trade Organization (Persetujuan Pembentukan Organisasi Perdagangan Dunia). Konsekuensi logis dan psikologisnya, Indonesia harus menerapkan hukum IPR/HKI tersebut sebagaimana tuntutan dari TRIP's Agreement dan Konvensi Paris.

Perkembangan internasional tersebut justru mempengaruhi perkembangan hukum nasional, sehingga terjadi saling terkait antara perkembangan hukum internasional dengan hukum nasional masing-masing negara, terciptanya arena transnasional dalam praktek hukum yang bersumber dari kekuatan-kekuatan dan logika yang bekerja dalam bidang ekonomi (Candra Irawan, 2). Globalisasi memberikan pengaruh besar terhadap aspek hukum dengan implikasi globalisasi ekonomi, sehingga substansi Undang-undang Desain Industri dipengaruhi oleh perjanjian-perjanjian internasional, menyebar melewati batas-batas negara (cross border). Berbagai negara, baik negara maju, negara berkembang maupun negara terbelakang harus membuat standarisasi hukum dalam ekonominya (Bismar Nasution, 2003: 7). Salah satu bentuk standarisasi hukum adalah peraturan mengenai Hak Kekayaan Intelektual sebagaimana disepakati dalam TRIP's Agreement.

\section{Internalisasi Nilai-Nilai Keadilan Sosial Ke Dalam Undang-Undang Desain Industri}

Muatan materi yang ada pada UU Desain Industri masih menyimpan beberapa kelemahan, yang muncul dalam muatan materi berdampak dan berpengaruh terhadap implementasinya. Setidaknya ada dua kelemahan yang terkandung dalam Undang-Undang Desain Industri yang terletak pada; (Budi Agus Riswandi, 413) Pertama, ketentuan Pasal 1 UU Desain Industri yang dijelaskan bahwa unsur desain industri harus mengandung kesan estetika. Akan tetapi batasan-batasan obyektif atas suatu kreasi yang mempunyai kesan estetis tidak dijelaskan dalam UU Desain Industri, untuk mengatakan suatu kreasi mempunyai kesan estetis sangat subyektif, UU tidak memberikan penegasan siapa yang mempunyai hak untuk menentukan suatu kreasi mempunyai kesan estetis atau tidak adalah dilakukan oleh Dirjen HAKI. Kedua, dalam proses pendaftaran desain industri yang mengandung ketidakadilan hukum antara Pasal 26 dan Pasal 29 UU Desain Industri. Hal ini dibuktikan dimana di satu sisi apabila dalam Pengumuman Permohonan desain industri itu ada keberatan dari pihak ketiga, 
DE LEGA LATA

Jurnal Ilmu Hukum

FAKULTAS HUKUM UMSU
Perlindungan Hukum Kekayaan Intelektual...(Ida Nadirah)

Volume 5 Nomor 1, Januari - Juni 2020, 37-50

DOI: https://doi.org/10.30596/dll.v4i2.3176

maka pemeriksaan akan dilakukan secara subtantif. Namun ketika tidak ada keberatan atas permohonan Dirjen HAKI begitu saja memberikan hak desain industri.

Pasal-pasal terkait dalam UUD 1945 Pasal 18 ayat (5) UUD 1945 bahwa "Pemerintahan daerah menjalankan otonomi seluas-luasnya, kecuali urusan pemerintahan yang oleh undangundang ditentukan sebagai urusan Pemerintah Pusat" merupakan "pesan keadilan dalam bidang pemerintahan". Pasal 33 ayat 3 UUD 1945 bahwa "Bumi dan air dan kekayaan alam yang terkandung di dalamnya dikuasai oleh negara dan dipergunakan untuk sebesar-besar kemakmuran rakyat" merupakan "pesan keadilan dalam bidang ekonomi". Jelasnya, seluruh muatan UUD 1945 memerintahkan perwujudan keadilan sosial dalam segala aspek kehidupan. Dengan Keadilan Sosial Bagi Seluruh Rakyat Indonesia, dimaksudkan bahwa setiap insan masyarakat Indonesia harus menjadi orang yang menegakkan nilai-nilai keadilan sosial, yang bisa dimulai dengan bersikap adil dalam keluarga, bersikap adil dalam menyelesaikan persoalan-persoalan dalam lingkungan bermasyarakat. Jika nilai-nilai ini sudah merasuk ke "sukma" atau "jiwa" dan menjadi gaya hidup, maka ketika seseorang menempati jabatanjabatan fungsional publik, maka nilai-nilai keadilan sosial akan terjawantah dengan baik dalam berbagai kebijakan publik demi melayani masyarakat.

\section{KESIMPULAN}

Perlindungan hak desain industri yang didapat seseorang/kreator yang telah mendapat persetujuan dari Permohonan Pendaftaran Desain Industri ke Direktorat HKI adalah mendapat Hak Desain Industri atau berhak untuk monopoli selama 10 (sepuluh) tahun. Pemegang Hak Desain Industri ini mempunyai hak untuk memberi izin atau melarang orang lain untuk membuat, menjual, mengimpor, mengekspor atau mengedarkan barang yang telah diberikan Hak Desain Industri.

Kurangnya pengharagaan pendesain terhadap kreasinya karena wawasan tentang desain; serta adanya anggapan bahwa penelitian desain butuh biaya yang mahal, di sisi lain belum adanya kejelasan hubungan antara industri dengan pendesain. Posisi rawan dari pengrajin kerajinan tangan dikarenakan Kurangnya pemberdayaan pengrajin kerajian tangan melalui perlindungan hukum desain industri. Selain itu faktor-faktor penghambat para pengrajin/pendesain dalam pemberdayaan pengrajin kerajinan tangan disebabkan: Satu, belum memahami tentang desain industri; Dua, belum memahami manfaat secara ekonomis dan yuridis dari pendaftaran hak atas desain industri yang mereka ciptakan; Tiga, kurang sosialisasi; Empat, pengaruh konsep budaya (komunal) yang melekat pada konsep berpikir pengrajin kerajinan tangan; Lima, tidak mengetahui syarat yang harus dilengkapi; Enam, tidak mengetahui kriteria dari desain yang dapat dimohonkan pendaftarannya; Tujuh, tidak tahu tata cata untuk mengajikan permohonan pendaftarannya; Delapan, takut terbeban pajak yang tinggi; Sembilan, takut berdosa, karena menganggap bahwa kreativitas yang dimiliki didapat dari milik nenek moyanng; Sepuluh, tidak mempunyai biaya/modal untuk mendaftarkan

\section{SARAN}

Ditinjau dari sudut kreator: era globalisasi (MEA) mendorong pengrajin kerajinan tangan untuk kritis dan kreatif dalam menyikapi setiap tindakan dan batasan-batasan, sehingga tidak tertindas dalam ketidakadilan sosial. Para pengrajin misalnya harus melahirkan kerajinan 
DE IEGA LATA

Jurnal Ilmu Hukum

FAKULTAS HUKUM UMSU

tangan dari bahan yang berasal dari berbagai daerah yang "trend" dan "elegant" sehingga kerajinan tangan dapat menjadi komoditas dagang yang mampu bersaing di pasar domestik maupun internasional. Kreativitas dari para pengrajin dan desainer merupakan kunci dalam pasar global.

Dari sudut substansi undang-undang: Desain Industri harus dilakukan amandemen dengan memasukkan nilai-nilai keadilan sosial ke dalam undang-undang tersebut. Dari sudut kebijakan pemerintah: perlu dilakukan sosialisasi intensif dan memberikan pancingan berupa hadiah bagi mereka yang berhasil mengimplementasikan kreasinya ataupun memberikan dana talangan atau dana stimulant kepada pengrajin kerajinan tangan sebagai biaya untuk mendaftarkan desain kreativitasnya ke Ditjen HKI untuk mendapatkan perlindungan hukumnya.

Diupayakan adanya perlindungan hukum yang bersifat kedaerahan atau mungkin yang bersifat "sui generis", dilakukan inventarisasi, pengadministrasian yang selanjutnya diberikan/diupayakan konsep perda untuk mendapatkan perlindungan hukum di daerah kemudian diusulkan untuk selanjutnya dilakukan amandemen dengan mengacu pada kepentingan hukum di daerah. 
Jurnal Ilmu Hukum FAKULTAS HUKUM UMSU
Perlindungan Hukum Kekayaan Intelektual...(Ida Nadirah)

Volume 5 Nomor 1, Januari - Juni 2020, 37-50

DOI: https://doi.org/10.30596/dll.v4i2.3176

\section{DAFTAR PUSTAKA}

Faisal. (2018). Akibat Hukum Ketiadaan Akta Ikrar Wakaf Atas Perwakafan Tanah, 3, (2), 143 153. https://doi.org/10.30596/dll.v3i2.3154.

Hadjon, Phillipus M. (1987). Perlindungan Hukum Bagi Rakyat Indonesia. Surabaya: Bina Ilmu.

Hariyani, Iswi. (2010). Prosedur Mengurus HAKI (Hak Atas Kekayaan Intelektual) Yang Besar, Jakarta: Pustaka Yustisia

Hartono, Sunaryati. (1991). Politik Hukum Menuju Satu Sistem Hukum Nasional. Bandung: Alumni

http://www.investor.co.id/opini/urgensi-pendidikan-desain-dan-inovasi-produk/30725 diunduh tgl 8 juli 2019 Ernawati dalam Copyright @ Sinar Harapan 2003

http://www.sinarharapan.co.id/eknomi/industri/2019/0910/ind1.html.

Indratmoko Poerwanto, Message 1 of 1, Nov 2, 1999 dan Bisnis Indonesia Edisi: 03-NOV1999, Menanti UU desain produk industri, penulis menempuh studi master pada Department of Industrial Design, Arizona State University.

Kepala Direktorat Jenderal HKI, Abdul Bari Azed diakses dari http://www.sinarharapan.co.id/ekonomi/industri/2019/0910/ind1.html.

Maulana, Insan Budi. (2010). A-B-C Desain Industri Teori dan Praktek di Indonesia. Bandung, Citra Aditya Bakti.

Nasution. Bismar. (2003). Pengaruh Globalisasi Ekonomi Pada Hukum Indonesia, Majalah Hukum Medan, Fakultas Hukum USU, Vol. 6.

R. F, Mayana. (2011). Perlindungan Desain Industri di Indonesia dan Ketentuan Internasional di Bidang Desain Industri. Panitia Pelatihan Konsultan Hak Kekayaan Intelektual. Kerjasama antara Fakultas Hukum Universitas Padjajaran dan Direktorat Jenderal HKI Kementerian Hukum dan HAM RI.

Rahardjo, Satjipto. (1996). Pembangunan Hukum Di Indonesia Dalam Konteks Global, Makalah Pada Pertemuan Dosen Pengajar Sosiologi Hukum Se-Jawa Tengah dan Daerah Istimewa Yogyakarta, Universitas Muhammdiyah Solo (UMS) tanggal 5-6 Agustus 1996.

Ramadhani, Rahmat. (2017). Jaminan Kepastian Hukum Yang Terkandung Dalam Sertipikat Hak Atas Tanah, 2, (1), 139-157. https://doi.org/10.30596/dll.v2i1.1144

Rasjidi, Lili., I. B. Wyasa Putra. (1993). Hukum Sebagai Suatu Sistem. Bandung: Remaja Rusdakarya.

Saidin, OK. (2004). Aspek Hukum Hak Kekayaan Intelektual (Intellectual Property Rights). Jakarta: Grafindo.

Utomo, Tomi Suryo. (2009). Hak Kekayaan Intelektual (HKI) di Era Global (Sebuah Kajian Kontemporer). 